\title{
"Trends in the developing Ukrainian non-bank financial service markets assessed using a mixture separation method"
}

\begin{tabular}{|c|c|}
\hline AUTHORS & $\begin{array}{l}\text { Nataliya Vnukova (i) } \\
\text { R } \\
\text { Robert Bacho (D) } \\
\mathbb{R}\end{array}$ \\
\hline ARTICLE INFO & $\begin{array}{l}\text { Nataliya Vnukova and Robert Bacho (2020). Trends in the developing Ukrainian } \\
\text { non-bank financial service markets assessed using a mixture separation method. } \\
\text { Economics of Development, 19(4), 48-60. doi:10.21511/ed.19(4).2020.05 }\end{array}$ \\
\hline DOI & http://dx.doi.org/10.21511/ed.19(4).2020.05 \\
\hline RELEASED ON & Tuesday, 18 May 2021 \\
\hline RECEIVED ON & Wednesday, 20 May 2020 \\
\hline ACCEPTED ON & Monday, 07 December 2020 \\
\hline LICENSE & $\begin{array}{l}(\mathrm{cc}) \overline{\mathrm{EY}} \\
\text { This work is licensed under a Creative Commons Attribution } 4.0 \text { International } \\
\text { License }\end{array}$ \\
\hline JOURNAL & "Economics of Development" \\
\hline ISSN PRINT & $1683-1942$ \\
\hline ISSN ONLINE & $1683-1942$ \\
\hline PUBLISHER & LLC "Consulting Publishing Company "Business Perspectives" \\
\hline FOUNDER & Simon Kuznets Kharkiv National University of Economics \\
\hline
\end{tabular}

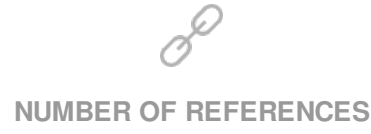

19

\section{NUMBER OF FIGURES}

2

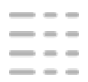

NUMBER OF TABLES

1

(C) The author(s) 2021. This publication is an open access article. 


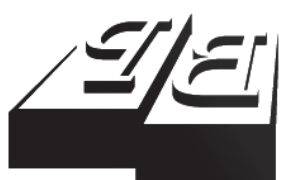

BUSINESS PERSPECTIVES

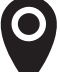

Publisher

LLC "CPC "Business Perspectives" Hryhorii Skovoroda lane, 10, Sumy, 40022, Ukraine www.businessperspectives.org

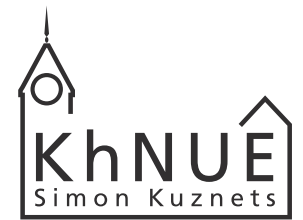

\section{S. KUZNETS KHNUE}

Founder

Simon Kuznets Kharkiv National University of Economics, Nauky avenue, 9-A, Kharkiv, 61166,

Ukraine

http://www.hneu.edu.ua/

Received on: 20th of May, 2020 Accepted on: 07th of December, 2020 Published on: 18th of May, 2021

(C) Nataliya Vnukova,

Robert Bacho, 2021

Nataliya Vnukova, Doctor of Economics, Professor, Simon Kuznets Kharkiv National University of Economics, Ukraine.

Robert Bacho, Doctor of

Economics, Professor, University of Nyíregyháza, Hungary.

\title{
TRENDS IN THE DEVELOPING UKRAINIAN NON-BANK FINANCIAL SERVICE MARKETS ASSESSED USING A MIXTURE SEPARATION METHOD
}

\begin{abstract}
Non-bank financial institutions play an important role in the non-bank financial service markets expressed in expanding the access to financial services for individuals and legal entities. The non-bank financial service markets demonstrate their performance peculiarities in the pre-crisis and post-crisis periods that bring up to date the need to form a scientific presentation of their development trends. Therefore, it is necessary to provide scientific background and identify the regress and progress processes in the non-bank financial service markets.

The research aim is to develop an analytical approach to determining the peculiarities of the development processes in the non-bank financial service markets. The research assesses the key indicators of the non-bank financial service markets in terms of quantity by dividing a set of values into groups by cluster analysis and multidimensional object clustering by a system of indicators, as well as identifying the progress and regress patterns in the non-bank financial service markets.

Achieving the research results requires taking into account the above-mentioned objectives fulfilled in seven stages.

The research results reflect the influence on the financial service markets exerted by the governmental regulation policy and the consumer protection level in these markets.
\end{abstract}

\section{(c) (i)}

This is an Open Access article, distributed under the terms of the Creative Commons Attribution 4.0 International license, which permits unrestricted re-use, distribution, and reproduction in any medium, provided the original work is properly cited.
Keywords

Н. М. Внукова (Україна), Р. Й. Бачо (Угорщина) credit unions, regulation

G23, G28
JEL Classification

financial services, non-bank institutions, insurance,

\section{ОЦІНКА ТЕНДЕНЦІЙ СУЧАСНОГО РОЗВИТКУ РИНКІВ НЕБАНКІВСЬКИХ ФІНАНСОВИХ ПОСЛУГ УКРАЇНИ ІЗ ЗАСТОСУВАННЯМ МЕТОДУ 3 РОЗДІЛЕННЯ СУМІШІ}

\section{Анотація}

Небанківські фінансові установи відіграють важливу роль на ринках небанківських фінансових послуг щодо розширення доступу фізичних та юридичних осіб до фінансових послуг. Враховуючи особливості функціонування небанківських ринків фінансових послуг у докризовий та посткризовий період, актуалізується необхідність формування наукової формалізації тенденцій їх розвитку.

Таким чином, дослідження, присвячені науковій аргументації та встановленню процесів регресу та прогресу на небанківських ринках фінансових послуг є необхідними.

Метою дослідження є розробка аналітичного підходу для визначення особливостей процесів розвитку небанківських ринків фінансових послуг. У дослідженні проведено кількісну оцінку ключових індикаторів розвитку небанківських ринків фінансових послуг шляхом розподілу показників на групи з використанням кластерного аналізу та багатовимірної кластеризації об’єктів за системою показників, а також виявлення закономірностей прогресу та регресу на ринках небанківських фінансових послуг.

Отримання результатів може бути досягнуто з урахуванням вищезазначених передумов з їх виконанням у сім етапів. 
Результати дослідженння визначають вплив політики державного регулювання на ринки фінансових послуг та рівень захисту прав споживачів на досліджуваних ринках.

Отримання бажаних результатів дослідження може бути отримано з урахуванням вищезазначених цілей та виконання їх у сім етапів. Результати досліджень визначають вплив політики державного регулювання на ринки фінансових послуг та рівень захисту прав споживачів на досліджуваних ринках.

Ключові слова

Класифікація JEL фінансові послуги, небанківські фінансові установи, страхування, кредитні спілки, регулювання G23, G28

\section{INTRODUCTION}

In modern conditions of deepening economic relations, non-bank financial institutions play an important role in the markets of non-bank financial services (NBFS) displayed in expanding the access to financial services for individuals and legal entities. The functioning of these institutions helps to stimulate financial and economic relations between economic entities at the micro-, meso- and macroeconomic levels. Given the volatility of the basic factors influencing the non-bank financial service markets, there is a need to identify these factors as well as the trends in internal processes occurring in the NBFS markets. The global financial and economic crisis of 2008-2009 showed the vulnerability of domestic financial service markets and their dependence on external influences. Negative expectations of deteriorating economic conditions in the world and Ukraine, in particular, due to the negative impact of coronavirus disease, create new challenges for government regulation in the NBFS markets.

To establish clear recommendations by state regulators for non-bank financial service markets, the latter need to identify changing conditions in the studied markets in a timely manner. Therefore, the research works devoted to scientific argumentation and establishment of regress and progress processes in the NBFS markets are updated.

\section{LITERATURE REVIEW}

This research included the scientific works by Maliarets (2006), Maliarets (2008), Ponomarenko and Maliarets (2009) devoted to systematization and development of economic and mathematical models representing the development trends of the chosen research targets in retrospect.

Masciandaro and Quintyn (2009) as well as Čihák and Podpiera (2006) considered the possibility of introducing a single regulator (megaregulator) in the financial service markets with a view to a new financial architecture. Ingves (2011) studied the impact of the new Basel standards on the stability of banking financial institutions and confirmed the need to improve the existing banking regulation. Goodhart and Tsomocos (2012) explored the issue of ensuring financial stability in the financial service markets, assessing the regulatory impact on the development of the studied markets.

The development trends of the financial service market have been influenced by the reformed international AML system with the adaptation mechanism introduction in the state regulation sphere representing one of its elements. Ponomarenko et al. (2019) assessed the impact exerted by the level of state regulation and supervision on the development of the risk-oriented AML system based on a five-level hierarchical model applied to the development of this system using Saati's hierarchy analysis method.

The current transformation stage in the financial service market following the introduced risk-oriented approach in Ukraine is marked by changes in the financial monitoring system as evaluated by Vnukova et al. (2020) through to the probable determination of the connectivity among insurance companies using the graph theory tools and indicator markers.

Macroprudential features seen in the regulation of the financial service markets are revealed in Hirtle et al. (2009). Kolodiziev and Lozynska (2020) and other researchers explored current trends in the digital transformation (digitalization) of the financial service market and the peculiarities of changes in the banking system. 
The works presented by the above-mentioned scientists do not provide means for determining the development features peculiar to the non-bank financial service markets taking into account the possibilities of the improvement dynamics or deterioration of the basic indicators which characterize the performance of the non-bank financial service markets. Therefore, it is necessary to develop a special analytical and information approach that will reflect the above patterns.

\section{AIMS}

The research is aimed at developing an analytical approach to determine the peculiarities of the development processes in the NBFS markets, which assesses the key indicators of the NBFS markets quantitatively by dividing the set of values into groups with the help of cluster analysis and multidimensional clustering of objects by a system of indicators, as well as identifying patterns of progress and regress in the non-bank financial service markets.

\section{METHODS}

The scientific advances in Ponomarenko and Maliarets (2009) formed a base for building the law of value distribution with regard to each of the studied indicators applicable to the NBFS markets. It is possible to confirm or refute the existing homogeneity or heterogeneity against an array of statistical samples while calculating the normal distribution for the selected indicators.

Summarizing the primary information collected and published on the official website of the body that carried out state regulation of the financial service markets in Ukraine for 2006-2018 provided a set of statistical information for the study.

A hypothesis about the simultaneous existence of several distribution laws is formed by solving a mathematical problem on the distribution of a mixture proposed by Pearson (1986). The differential and integral distribution functions of a mixture of two components are expressed as a linear combination of normal distributions, by determining certain parameters based on the method of moments. The set of values is divided into groups by means of cluster analysis using a centroid connection and Ward's method (Brucker, 1974). Finally, the multidimensional clustering of objects by a system of indicators (Anderberg, 1973) makes it possible to establish the course of two opposite processes, namely, progress and regress.

The desired research results can be obtained taking into account the above objectives and fulfilling them in the following sequence: analyzing scientific and statistical sources to choose the indicators applied for assessing the development of the NBFS markets while forming a system of indicators to assess their development; establishing laws for the distributed values of each studied indicator of the NBFS markets; forming a hypothesis about the simultaneous existence of several distribution laws for each of the indicators; dividing the set of indicator values into groups by solving the problem of mixture division; building laws of value distribution of an indicator in each cluster; calculating the centroid values in each cluster of indicator values; determining the type of development process for the specific indicators of the NBFS markets, namely, progress or regress, building a dendrogram that reflects the stratification of indicator values; grouping the indicators that characterize specific NBFS markets and carrying out cluster analysis, selecting clusters, determining the value of their centroids; determining the development process type for certain NBFS markets, building a dendrogram that reflects the stratification of objects by clusters.

\section{RESULTS}

The existing performance peculiarities of the non-bank financial service (NBFS) markets in the pre-crisis and post-crisis periods actualize the need to form a scientific presentation of their development trends. Given that the 
NBFS markets are described by the heterogeneity of characteristics (each of these markets has its own economic nature of operation) (Pukala et al., 2019) and a broad set of indicators (specific indicators for each of the markets differ from the economic content of the other market), and since the existing scientific approaches illustrate the lack of tools to identify the relationship building among various features aimed at determining the main factors (Maliarets, 2008) that drive the development of the NBFS markets, the need to specify approaches to the analytical presentation of such changes becomes urgent.

To represent the development trends of the NBFS markets in Ukraine as following from the scientific developments (Maliarets, 2006; Ponomarenko \& Maliarets, 2009), the authors have formed an analytical approach, the use of which involves several stages.

Stage 1. Forming a system of indicators that characterizes the performance of the NBFS markets. The list of indicators with the assigned symbols that have been analytically processed is based on the existing data presented in Table 1.

Stage 2. Building a value distribution law for each of the selected indicators. Confirmation or refutation of the homogeneity or heterogeneity of the statistical sample array (Maliarets, 2006) while calculating the normal indicator distribution $\left(\mathrm{x}_{1} \ldots k_{14}\right)$.

The calculation of the normal indicator distribution $\left(\mathrm{x}_{1} \ldots k_{14}\right)$ provides means for confirming or refuting the existing homogeneity or heterogeneity of the statistical sample array (Maliarets, 2006). Confirmed or refuted, the heterogeneity of the statistical sample array (inhomogeneous arrays differ at least by a vector of averages) indicates the existence or absence of several normally distributed subsets, respectively.

Stage 3. Forming a hypothesis of several distribution laws that operate simultaneously. By confirming or refuting this hypothesis, the existence of different processes has been scientifically proved, which in turn leads to the conclusion about the presence/absence of structural changes in the respective NBFS market. For this reason, it is necessary to divide the present sets by solving a mathematical problem on the mixture division proposed by Pearson (Rissanen, 1986). The scientist suggests the representation of asymmetric distributions of the mixture by two normal laws (Ponomarenko \& Maliarets, 2009), i.e. two separate normal distributions can be uniquely restored by the mixture distribution (Maliarets, 2006).

The differential and integral distribution functions of a mixture of two components are expressed as a linear combination of normal distributions containing 5 parameters (Maliarets, 2006):

$f(x)=p_{1} \cdot f_{1}(x)+p_{2} \cdot f_{2}(x)$,

$F(x)=p_{1} \cdot F_{1}(x)+p_{2} \cdot F_{2}(x)$,

where $f_{i}(x)=\frac{1}{\sqrt{2 \pi \cdot \delta_{i}}} \exp \left\{-\frac{\left(x-a_{i}\right)^{2}}{2 \cdot \delta_{i}^{2}}\right\}, F(x)=\int_{-\infty}^{x} f_{i}(t) d t, p_{1,} p_{2}-$ probabilities by which the normall y distributed components are mixed, with $p_{1}+p_{2}=1, a_{i}$ - mathematical expectations of individual distributions, $\delta_{\mathrm{i}}-$ mean squared deviations of the individual distributions.

While determining the parameters of individual distributions, the method of moments was applied. The smoothed function for each of the studied indicators is represented in Figure 1. The obtained graphs of the smoothed functions prove the existence of several sets of features, which is confirmed by the pronounced "breaks" (waveform) of the built graphs for each of the studied parameters. In order to represent such changes numerically, it is necessary to separate the sets into corresponding groups by means of cluster analysis.

Stage 4. Dividing the set of values into groups by cluster analysis. It is proposed to use cluster analysis at this stage, which will offer a means for determining the number of components and their composition based on the mixture data. This approach rests upon the fact that over the last decades, significant progress has been made in cluster analysis, and some current varieties of analysis are credible in the classification objectivity. Within the scope of 
cluster analysis, one of the main basic points of qualitative calculation and results presentation is the choice of the distance between the groups of objects (clusters), which may include about twelve different methods, the most common of which are centroid linkage and Ward's method. The first method is characterized by comparing the distance between their centers, and the second one determines the proximity of the two clusters by combining them and determining the minimum increment of the total variance. The advantage of using Ward's method to classify objects while measuring the feature size is expressed by the ability to identify clusters of nearly the same size (Ponomarenko \& Maliarets, 2009).

Stage 5. Calculating the numerical characteristics for each subset of the indicator values. Given that the analytical potential of solving the mixture split problems is the ability to separate subsets in the aggregate of the statistical information set and calculate the statistical characteristics of individual subsets, it is necessary to study the magnitude of the characteristics shown by specific indicators and determine the levels of indicator values that characterize the NBFS markets. For this purpose, the obtained calculations have been summarized in Table 1 from which it is seen that the data set of each indicator can be represented by two clusters. At the same time, one can distinguish certain features inherent in the process of indicator clustering.

Firstly, several indicators are divided by cluster analysis into two clusters, and in a chronological framework this is continuous, otherwise speaking, the set of features (years of study) in Cluster 2 represents a continuation of the Cluster 1 set of features. Such indicators are as follows (see the data in Table 1): $\mathrm{x}_{2}$ (non-bank financial institutions' assets), $y_{2}$ (a volume of the non-state pension insurance market), $z_{3}$ (a premium volume of the risk segment), $z_{7}$ (assets of insurance companies belonging to the risk segment), $z_{8}$ (a share of technical provisions in the total insurance reserves), $z_{9}$ (a share of the risk insurance companies' assets in the insurers' total assets), $z_{10}$ (a share of the risk insurance companies' reserves in assets), $v_{2}$ (a volume of life insurance premiums), $v_{3}$ (a share of life insurance premiums in gross premiums), $\mathrm{v}_{4}$ (a volume of insurance payments), $\mathrm{v}_{5}$ (a volume of redemption amounts), $\mathrm{v}_{6}(\mathrm{a}$ volume of insurance indemnities and redemption amounts), $\mathrm{v}_{8}$ (a volume of mathematical insurance reserves), $\mathrm{v}_{9}$ (life insurance assets of the insurance companies), $\mathrm{v}_{12}$ (HHI of life insurance), $\mathrm{g}_{1}$ (a number of the issued certificates of mandatory third-party insurance coverage), $\mathrm{g}_{2}$ (total premiums derived from mandatory third-party insurance coverage), $g_{3}$ (total insurance indemnities derived from mandatory third-party insurance coverage), $\mathrm{g}_{5}$ (an average value of mandatory third-party insurance coverage), $\mathrm{g}_{6}$ (a number of settled cases of mandatory third-party insurance coverage), $g_{7}$ (an average compensation for mandatory third-party insurance coverage), and $\mathrm{k}_{12}$ (a share of the reporting credit unions).

Secondly, several indicators are characterized by the presence of one cluster within a chronological row, that is, in the time frames, the initial period and the end period of the chronological row create another cluster (see Table 1).

In this case, the smoothed function assumes an undulating form, and the graph ends imitate the initial representation, which indicates the recurrence of economic processes in the final years of the study and at the initial stage. The indicators characterized by these features are as follows: $\mathrm{x}_{4}$ (a share of the NBF institutions' assets in GDP), $y_{3}$ (a volume of credit unions' services), $z_{12}$ (a share of the first 50 insurance companies included in the risk segment), $\mathrm{z}_{13}$ (HHI of the risk segment), $\mathrm{v}_{1}$ (a number of life insurance companies), $\mathrm{k}_{1}$ (a number of credit unions), $\mathrm{k}_{2}$ (a number of credit unions' members), $\mathrm{k}_{3}$ (a share of the population covered by credit cooperatives), $\mathrm{k}_{5}$ (a share of credit unions' productive assets), $\mathrm{k}_{8}$ (total contributions made by credit unions' members), $\mathrm{k}_{11}$ (a number of reporting credit unions).

Thirdly, it is necessary to mention a group of indicators displaying trends that count in favor of a certain cyclicality, process repetitiveness in the respective NBFS markets. This repeatability is confirmed by the presence of two clusters that alternate in chronological order. Put in other words, the chronological row of Clusters 1 and 2 is divided by time. Such "breaking" of clusters in chronological rows testifies to the cyclicality of processes. These indicators (Poyda-Nosyk \& Vdovenko, 2017) of the NBFS markets include $\mathrm{v}_{7}$ (a level of life insurance payments), $\mathrm{v}_{10}$ (a market share of the first three life insurance companies), $\mathrm{v}_{12}$ (HHI of the life insurance market), and $\mathrm{k}_{13}$ (a ratio of credit union borrowers to depositors).

Stage 6. Comparing centroids in each group and determining the development process type. Clustering and identifying the periods that determine the chronological framework of clusters enables us to assess the nature of the development process shown by specific indicators. With this in view, the research compared the calculated values 


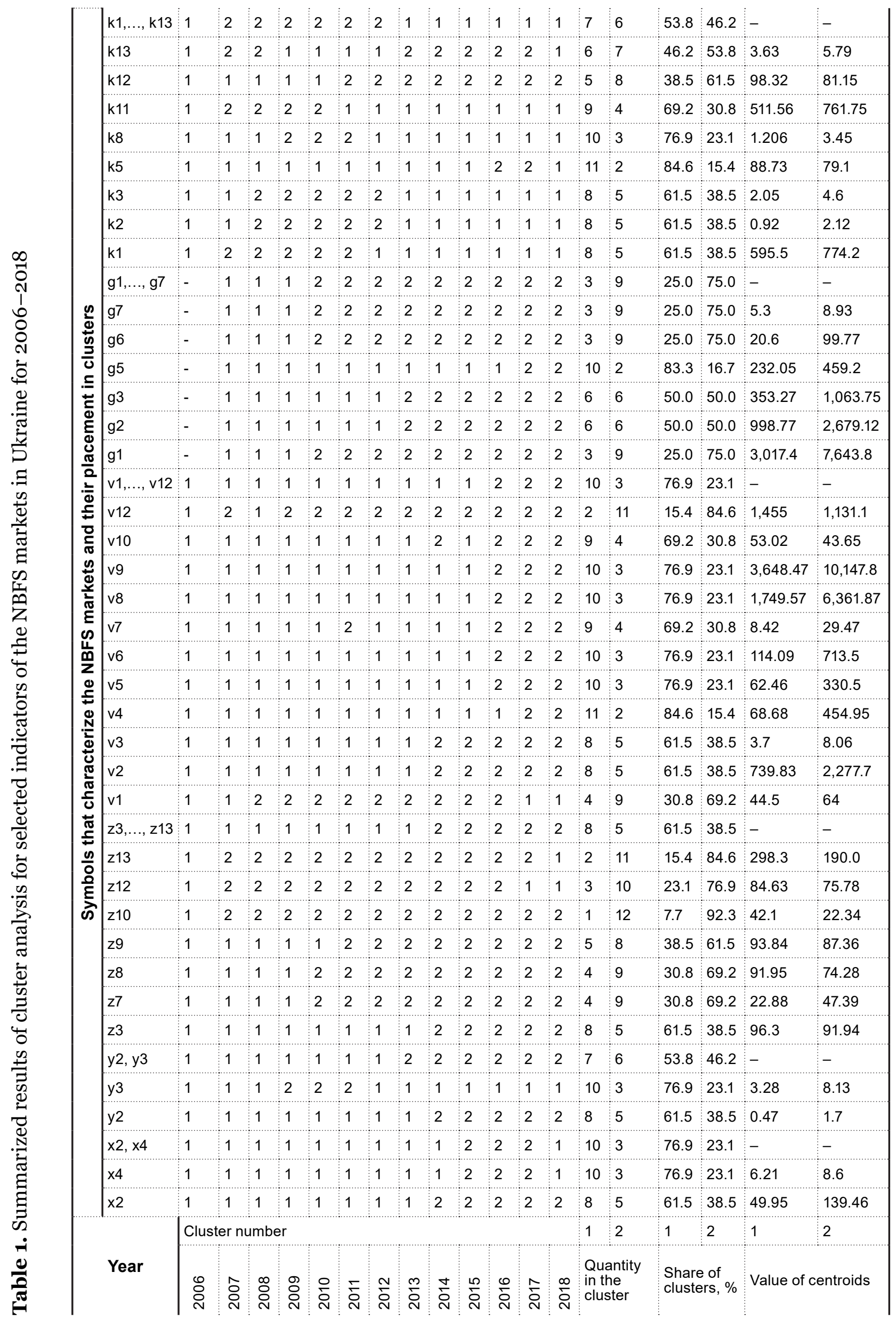


of the centroids (mean values) with regard to the selected clusters. The obtained values of centroids, when compared, make it possible to reach a conclusion on the progress or regress of the specified indicators.

It should be noted that the study examines two development types - progress and regress. Progress indicates a qualitative change in the indicator towards improvement, which in turn does not mean that the increase in the Cluster 2 centroid value compared to Cluster 1 testify to progress. Specific generalizations are in place to consider the economic nature of the indicator formation.

Comparisons of the calculated values of centroids derived from the studied indicators (see Table 1) allow us to form the following general conclusions:

1) regarding the indicators that are characterized by a chronological sequence of clusters:

- development regress is observed in indicators $z_{8}$ (a share of technical provisions in the total insurance reserves), $z_{9}$ (a share of the risk insurance companies' assets in the insurers' total assets), $z_{10}$ (a share of the risk insurance companies' reserves in assets), $\mathrm{v}_{2}$ (a volume of life insurance premiums), $\mathrm{k}_{12}$ (a share of reporting credit unions);

- development progress is stated in terms of $\mathrm{x}_{2}$ (non-bank financial institutions' assets), $\mathrm{y}_{2}$ (a volume of the non-state pension insurance market), $z_{3}$ (a premium volume of the risk segment), $z_{7}$ (assets of insurance companies belonging to the risk segment), $\mathrm{v}_{2}$ (a volume of life insurance premiums), $\mathrm{v}_{3}$ (a share of life insurance premiums in gross premiums), $\mathrm{v}_{4}$ (a volume of insurance payments), $\mathrm{v}_{5}$ (a volume of redemption amounts), $\mathrm{v}_{6}$ (a volume of insurance indemnities and redemption amounts), $\mathrm{v}_{8}$ (a volume of mathematical insurance reserves), $v_{9}$ (life insurance assets of the insurance companies), $v_{12}$ (HHI of life insurance), $g_{1}$ (a number of the issued certificates of mandatory third-party insurance coverage), $\mathrm{g}_{2}$ (total premiums derived from mandatory third-party insurance coverage), $g_{3}$ (total insurance indemnities derived from mandatory third-party insurance coverage), $g_{5}$ (an average value of mandatory third-party insurance coverage), $g_{6}$ (a number of settled cases of mandatory third-party insurance coverage), $g_{7}$ (an average compensation for mandatory third-party insurance coverage);

2) regarding the indicators that are characterized by one of the clusters present in the middle of the chronological row:

- development regress occurs in the middle of the sampling period at $\mathrm{k}_{5}$ (a share of credit unions' productive assets);

- development progress is observed in the middle of the sampling period at $\mathrm{x}_{4}$ (a share of the NBF institutions' assets in GDP), $y_{3}$ (a volume of credit unions' services), $z_{12}$ (a share of the first 50 insurance companies included in the risk segment), $\mathrm{z}_{13}$ (HHI of the risk segment), $\mathrm{v}_{1}$ (a number of life insurance companies), $\mathrm{k}_{1}$ (a number of credit unions), $\mathrm{k}_{2}$ (a number of credit unions' members), $\mathrm{k}_{3}$ (a share of the population covered by credit cooperatives), $\mathrm{k}_{8}$ (total contributions made by credit unions' members), and $\mathrm{k}_{11}$ (a number of reporting credit unions);

3) regarding the indicators characterized by process repeatability:

- progress follows the cyclical regress, and the chronological sequence ends with regress in the case of $\mathrm{k}_{13}$ indicator (a ratio of credit union borrowers to depositors);

- regress follows the cyclical progress, and the chronological sequence ends with progress for such indicators as $\mathrm{v}_{7}$ (a level of life insurance payments), $\mathrm{v}_{10}$ (a market share of the first three life insurance companies), $\mathrm{v}_{12}$ (HHI of the life insurance market). 


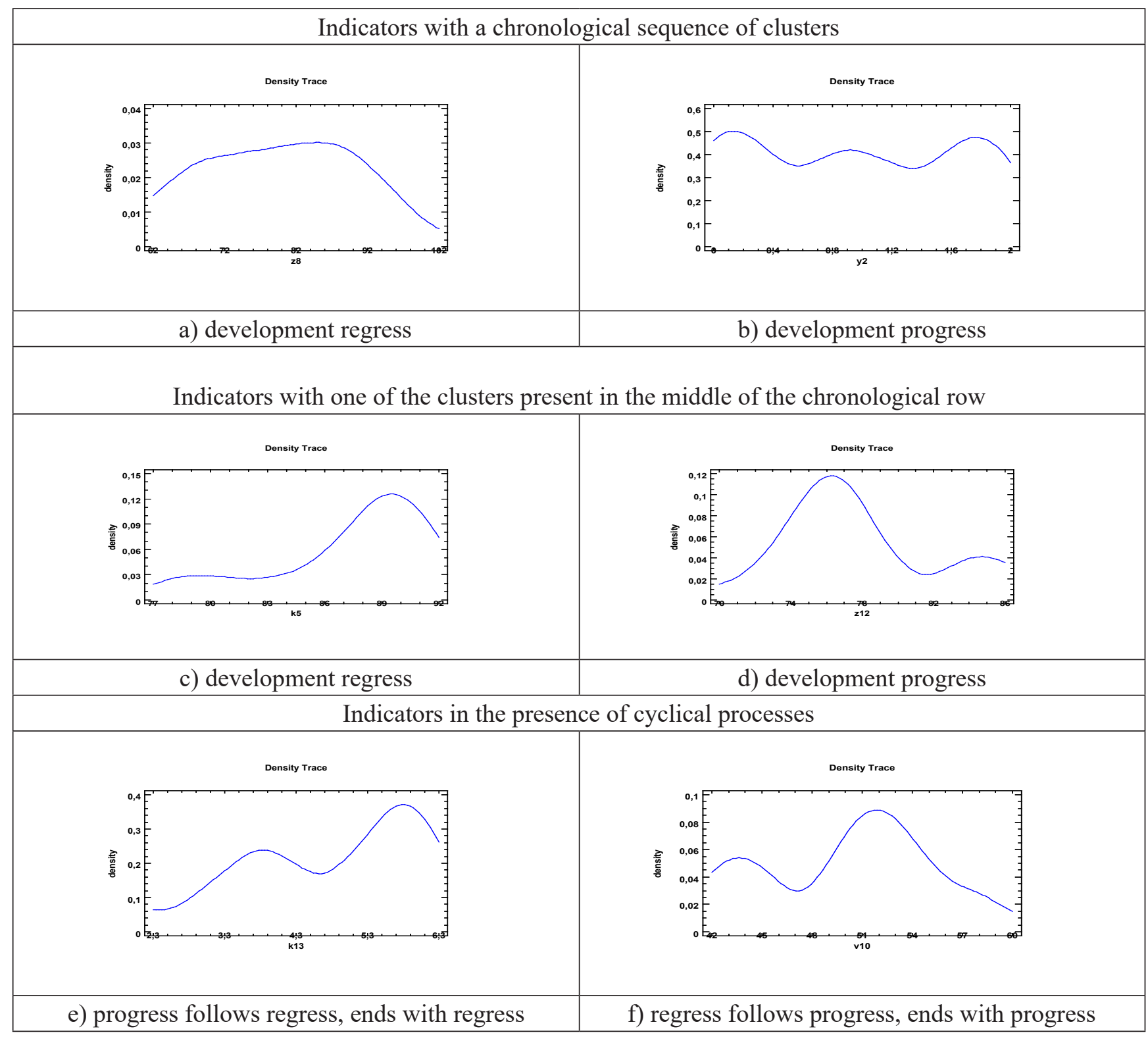

Source: Developed by the authors.

Figure 1. Examples of generalization patterns showing the development process of indicators by the cluster analysis method

Stage 7. Multidimensional clustering of objects (years) by the indicator system to determine the flow of the two processes.

Within the study scope, cluster analysis addressed not only single indicators, but also a group (set) of indicators that share common characteristics, that is, characterize specific NBFS markets, or NBFS markets in general (Table 1). The use of cluster analysis for a specific set of indicators explains the development trends in the NBFS markets studied. According to the calculations (Figure 2), common trends are effective for the non-state pension insurance market and credit cooperation, since Cluster 1 covers 2006-2012 and Cluster 2 - 2013-2018.

Two periods are clearly distinguished in the risk insurance segment: 2006-2013 and 2014-2018; 2006-2015 and 2016-2018 are identified for life insurance; 2007-2009 and 2010-2018 display mandatory third-party insurance coverage. It should be noted that the credit cooperative market is characterized by the presence of Cluster 2 (covering the period of 2007-2012), which separates the chronological framework of Cluster 1 for 2006 and the period of 2013-2018. 
Evaluating the indicators that characterize the assets of all non-bank financial institutions and the shares of all NBFS markets in GDP, the authors find a certain trend recurrence in 2018 with the trends for the period of 20062014, forming Cluster 1 as opposed to Cluster 2 (covering the period of 2015-2018).

At the same time, the impossibility of obtaining the cluster analysis results for the whole set of indicators underlines the authors' thesis about the existence of its own development trends for each of the studied NBFS markets and the need to study each of them separately.

Based on the developed analytical approach, it has been established that the NBFS markets are characterized by several periods distinguished by opposite development trends (Figure 2).

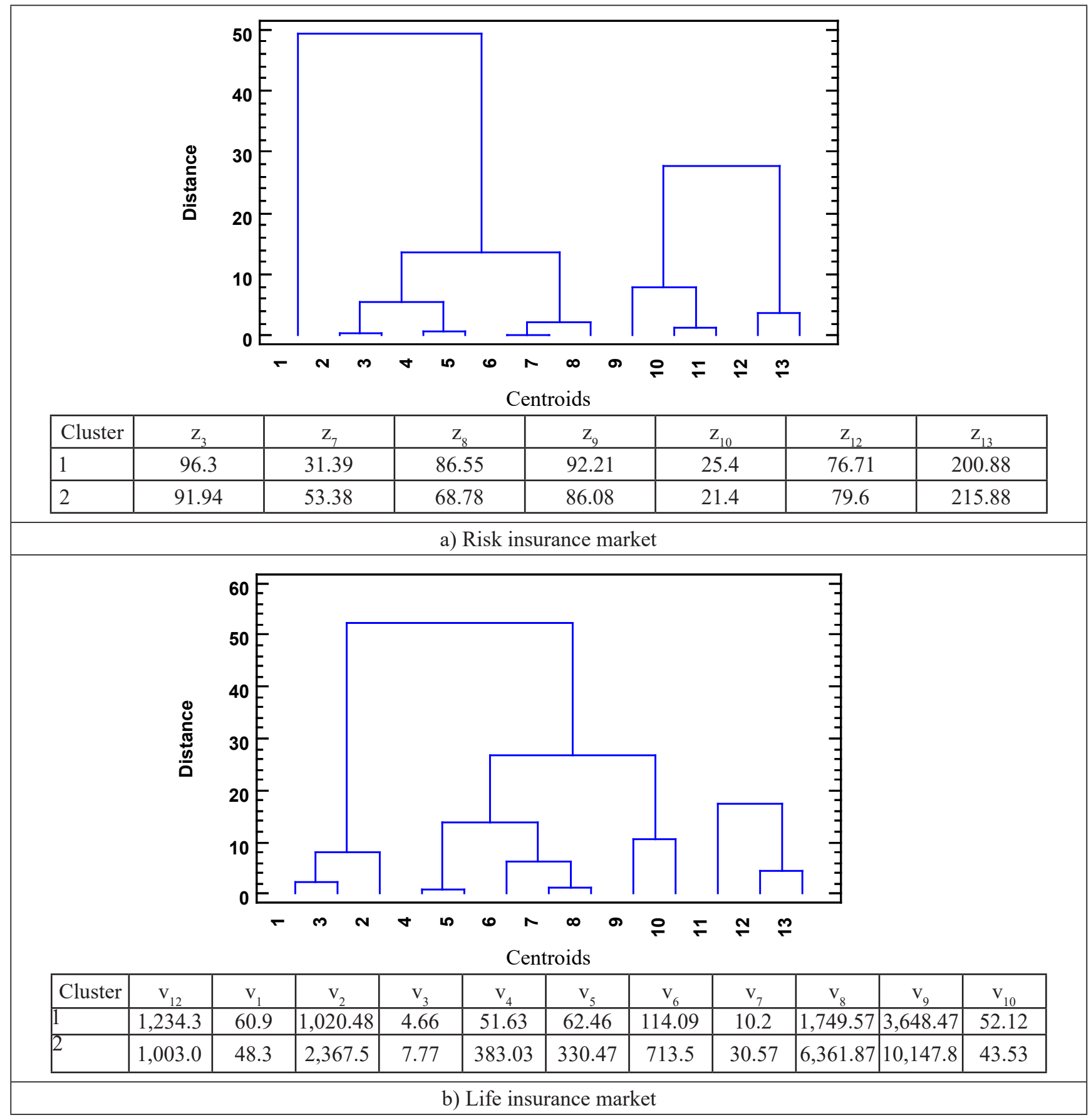

Figure 2. Results of the analytical approach applied to define the development processes in the NBFS markets 


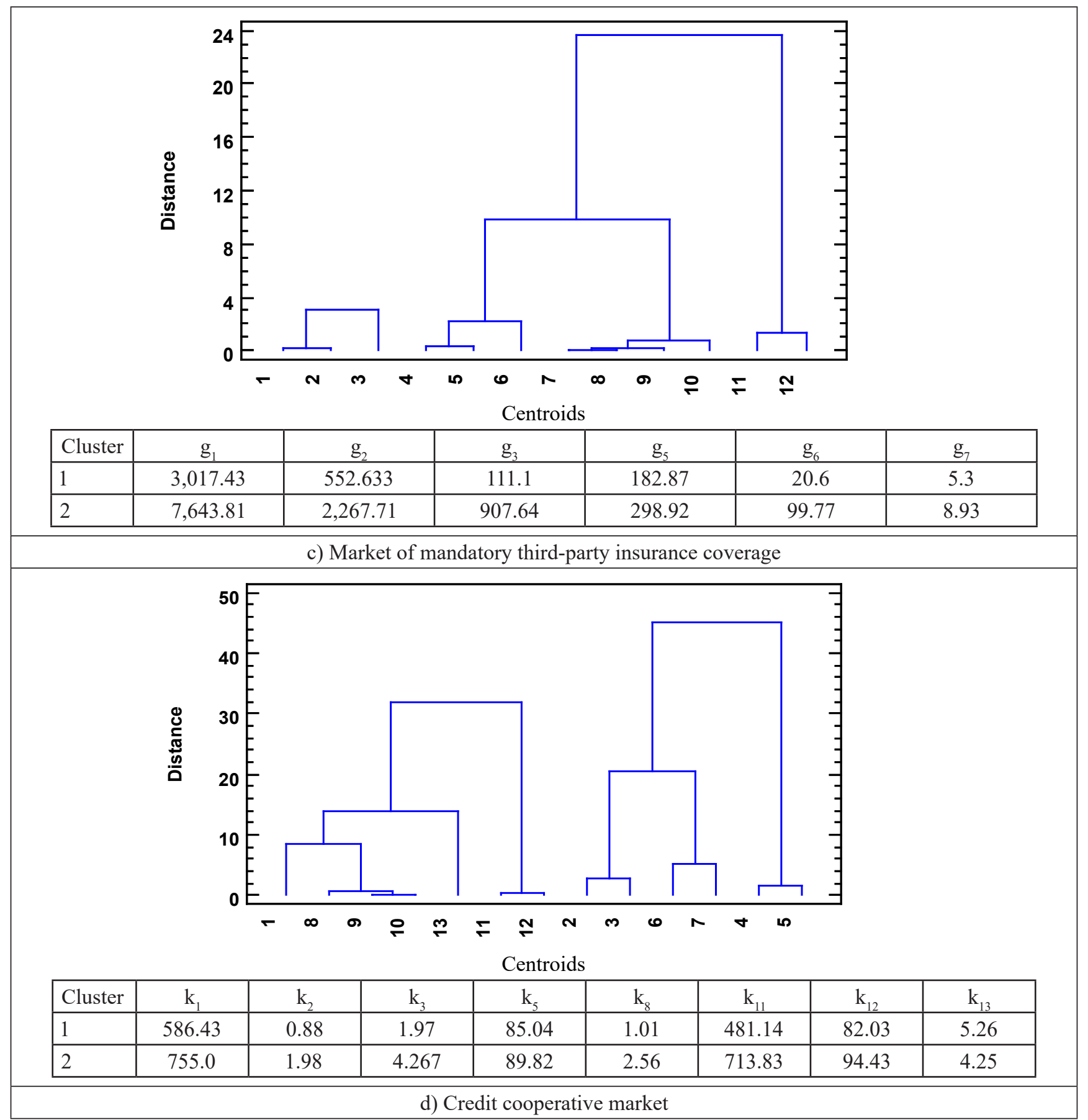

Source: Developed by the authors.

Figure 2 (cont). Results of the analytical approach applied to define the development processes in the NBFS markets

As can be seen from Figure 2, the insurance market is characterized by the following features (Figure 2, a-c): positive growth trends in risk insurance in 2006-2013, and since 2014 there has been a setback; more steady development in life insurance in 2016-2018 as opposed to the 2006-2015 recession; enhanced trends of sustainable development in the mandatory third-party insurance coverage market as observed in 2010-2018, which is confirmed by higher values of centroids for each of the indicators characterizing this market compared to the period of 2007-2009.

2007-2012 was the most favorable period for the development of the credit cooperation market (Figure 2d), which is characterized by the division of the chronological framework into three periods with sequential processes of progress and regress. 
Stage 8. Comparing the centroids in each group and determining the development process type by a system of indicators.

At the final stage of the analytical approach application, the results were summarized taking into account the aggregation of indicators and change directions in the numerical expression of the centroids of the formed clusters, as well as determining the process course in the NBFS markets.

Thus, the risk insurance market (Figure 2a) is characterized by two clusters: Cluster 2 (2014-2018) imitates Cluster 1 (covering 2006-2013), and the development progress is confirmed, which proves the increasing centroid values of the corresponding $z_{3}, z_{7}, z_{12}, z_{13}$ indicators. The decrease of the centroid values of $z_{8}, z_{9}, z_{10}$ indicators did not affect the overall assessment of the growth in this market, which is explained by the estimated nature of their obtaining, as the decrease in the risk segment share means a simultaneous growth of the life insurance market, which is generally desirable for Ukraine and corresponds to the insurance market trends in the EU countries.

The life insurance market (Figure $2 \mathrm{~b}$ ) is characterized by similar trends as the risk segment. However, the chronological framework of Cluster 2 is 3 years (2016-2018), which indicates more favorable conditions for functioning and ensuring the recent development of life insurance in Ukraine. As is clear from the data presented in Table 1 and Figure $2 \mathrm{~b}$, a reduced number of life insurance companies did not result in an increasing market concentration, since a decrease in the centroid value of $\mathrm{v}_{12}$ indicator testifies to increased competition in the market.

The mandatory third-party insurance coverage market (Figure 2c) has had a clear positive upward tendency since 2010. The centroid values of Cluster 1 and Cluster 2, when compared, confirm the thesis that the centroid values of $g_{1}, g_{2}, g_{3}, g_{5}, g_{6}$ and $g_{7}$ indicators in Cluster 2 are greater than the values of the similar Cluster 1 indicators.

A special situation is observed in the credit cooperative market (Figure 2d). The calculations prove that there are two clusters: Cluster 1 contains the chronological frames of 2006 and 2013-2018, while Cluster 2 addresses the period of 2007-2012. Based on the compared centroids of the indicators peculiar to each cluster, the authors conclude that the development of the credit cooperative market in Ukraine was characterized by regress in 2006, progress in 2007-2012, and repetitive regress in 2013-2018.

\section{CONCLUSIONS}

Consequently, the research was based on the proposed analytical approach to determine the course of processes in the NBFS markets, which provides quantification of key indicators reflecting the NBFS markets' performance by dividing the totality of values into groups by cluster analysis and performing multidimensional clustering of objects by the system of indicators, as well as the implementation of qualitative characteristics of the development level for the selected indicators based on the determined limit values of the latter, using the methods of multidimensional cluster analysis, Pearson's criterion, Ward's method, mathematical statistics and techniques (generalization, grouping, comparison), which determines the patterns of progress and regress in markets under the implementation of the policy adopted by the National Commission for State Regulation of Financial Service Markets regarding the activity of non-bank financial institutions and the protection of the NBFS consumer rights.

With the help of the obtained calculations related to the non-bank financial service markets in Ukraine, the periods of progress and regress have been determined, which is a precondition for determining the cyclical development of the studied markets in the future. Further development of this scientific issue will include establishing the strength of the influence of regulatory functions exerted by the central government on the relevant indicators that characterize the development of the studied markets. 


\section{AUTHORS CONTRIBUTIONS}

Conceptualization: Nataliya Vnukova.

Data curation: Robert Bacho.

Formal Analysis: Robert Bacho.

Funding acquisition: Robert Bacho.

Investigation: Robert Bacho, Nataliya Vnukova.

Methodology: Robert Bacho.

Project administration: Nataliya Vnukova.

Resources: Robert Bacho.

Software: Robert Bacho.

Supervision: Nataliya Vnukova.

Validation: Robert Bacho.

Visualization: Robert Bacho.

Writing - original draft: Robert Bacho.

Writing - review \& editing: Nataliya Vnukova.

\section{REFERENCES}

1. Anderberg, M. (1973). Cluster Analysis for Applications (376 p.). Cambridge: Academic Press. Retrieved from https://www.elsevier.com/ books/cluster-analysis-for-applications/anderberg/978-0-12-057650-0

2. Bacho, R., Pukala, R., Hlibko, S., Vnukova, N., \& Pola, P. (2019). Information management: the key driver of the economic system's development. Marketing and Management of Innovations, 3, 297-307. Retrieved from http://doi.org/10.21272/mmi.2019.3-23

3. Brucker, P. (1974). On the complexity of clustering problems (pp. 45-54). In Optimizations and Operations Research. Springer.

4. Čihák, M., \& Podpiera, R. (2006). Is One Watchdog Better than Three? International Experience with Integrated Financial-Sector Supervision. Czech Journal of Economics and Finance, 56(3-4), 102-126. Retrieved from https://journal.fsv.cuni.cz/mag/article/show/ $\mathrm{id} / 1048$

5. Goodhart, C., \& Tsomocos, D. (2012). Cheltenham: Financial Stability in Practice. Edward Elgar Publishing.

6. Hirtle, B., Schuermann, T., \& Stiroh, K. (2009). Macroprudential Supervision of Financial Institutions: Lessons from the SCAP (Staff Report no. 409). New York: Federal Reserve Bank of New York. Retrieved from https://www.newyorkfed.org/medialibrary/media/research/ staff_reports/sr409.pdf

7. Ingves, S. (2011). Basel: Bank for International Settlements. Central Bank Governance and Financial Stability.

8. Kolodiziev, O., \& Lozynska, O. (2020). Osoblyvosti vyznachennia ta strukturyzatsii rynku finansovykh posluh v umovakh didzhytalizatsii ekonomiky [Features of definition and structuring of the market of financial services in the conditions of digitalization of economy]. Bankivska sprava - Banking, 2(152), 41-56. (In Ukrainian). Retrieved from http://www.banking.hneu.edu.ua/wp-content/uploads/2020/12/ BS_2_2020_\%D0\%9A\%D0\%BE\%D0\%BB\%D0\%BE\%D0\%B4\%D1\%96\%D0\%B7\%D1\%94\%D0\%B2.pdf

9. Maliarets, L. (2006). Vymiriuvannia oznak obiektiv v ekonomitsi: metodolohiia ta praktyka [Measuring the characteristics of objects in economics: methodology and practice] (384 p.). Kharkiv: HNEU. (In Ukrainian)

10. Maliarets, L. (2008). Metodolohiia formuvannia modelnoho bazysu opysu sotsialno-ekonomichnykh system [Methodology of forming a model basis for the description of socio-economic systems]. Extended abstract of Doctor's thesis. Kharkiv: HNEU. (In Ukrainian)

11. Masciandaro, D., \& Quintyn, M. (2009). After the Big Bang and Before the Next One? Reforming the Financial Supervision Architecture and the Role of the Central Bank - A Review of Worldwide Trends, Causes and Effects (1998-2008) (Paolo Baffi Centre Research Paper No. 200937). Retrieved from https://papers.ssrn.com/sol3/papers.cfm?abstract_id=1336390

12. Masciandaro, D., \& Quintyn, M. (2011). The Economic Crisis: Did Financial Supervision Matter? (IMF Working Paper. No. 11/261). Retrieved from https://papers.ssrn.com/sol3/papers.cfm?abstract_id=1961908

13. Melecky, M., \& Podpiera, A. (2012). Institutional Structures of Financial Sector Supervision, Their Drivers and Emerging Benchmark Models (MPRA Paper No. 37059). Retrieved from https://mpra.ub.uni-muenchen.de/37059/1/MPRA_paper_37059.pdf

14. Nier, E., Osiński, J., Jácome, L., \& Madrid, P. (2011). Towards Effective Macroprudential Policy Frameworks: an Assessment of Stylized Institutional Models (Working Paper No. 11/250). Retrieved from https://www.imf.org/en/Publications/WP/Issues/2016/12/31/TowardsEffective-Macroprudential-Policy-Frameworks-An-Assessment-of-Stylized-Institutional-25322

15. Ponomarenko, V., \& Maliarets, L. (2009). Bahatovymirnyi analiz sotsialno-ekonomichnykh system [Multidimensional analysis of socioeconomic systems] (384 p.). Kharkiv: HNEU. (In Ukrainian). Retrieved from http://www.repository.hneu.edu.ua/handle/123456789/3113 
16. Ponomarenko, V., Vnukova, N., Kolodiziev, O., \& Achkasova, S. (2019). The influence of governmental regulation and supervision on the development of the risk-oriented system of financial monitoring of Ukraine. Financial and credit activity: problems of theory and practice, 2(29), 419-429. (In Ukrainian). https://doi.org/10.18371/fcaptp.v2i29.171986

17. Poyda-Nosyk, N., Bacho, R., \& Vdovenko, N. (2017). Comparative characteristic of development trends in the Polish and Ukrainian insurance markets: conclusions for Ukraine. Scientific Bulletin of Polissia, 3(11), 92-98. Retrieved from http://nbuv.gov.ua/UJRN/ nvp_2017_3\%281\%29_15

18. Rissanen, J. (1986). Stochastic complexity and modelling. The Annals of Statistics, 14(3), 1080-1100. https://doi.org/10.1214/ aos/1176350051

19. Vnukova, N., Kavun, S., Kolodiziev, O., Achkasova, S., \& Hontar, D. (2020). Indicators-Markers for Assessment of Probability of Insurance Companies Relatedness in Implementation of Risk-Oriented Approach. Economi Studies (Ikonomicheski Izsledvania), 32(1), 151-173. 